\title{
ANTIMICROBIAL PROTEINS ISOLATED FROM BOVINE CERVICAL MUCUS
}

\author{
J. BROWNLIE AND K. G. HIBBITT \\ Institute for Research on Animal Diseases, Compton, nr. Newbury, Berks.
}

(Received 12th December 1970, accepted 21st October 1971)

\begin{abstract}
Summary. Anionic and cationic proteins were isolated from cervical mucus obtained from the cow during oestrus. The anionic proteins showed no antimicrobial activity whereas the cationic proteins inhibited the growth of Staphylococcus aureus S305 and Brucella abortus S19. Polyacrylamide gel electrophoresis, immunoelectrophoresis and isoelectric focusing experiments revealed the heterogeneous nature of the cervical

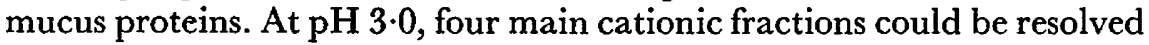
by disc acrylamide electrophoresis. By electrophoresis in agarose at $\mathrm{pH}$ $8 \cdot 6$, aggregation occurred, with the exception of a more basic fraction which migrated towards the cathode. Lysozyme was absent from the isolated soluble proteins of cervical mucus, but serum albumin, and $\beta$ - and $\gamma$-globulins were detected. Antimicrobial proteins in cervical mucus may provide an initial line of defence for the uterus against invading pathogens.
\end{abstract}

\section{INTRODUCTION}

Human cervical mucus has been shown to possess an antimicrobial activity and to be resolved, after electrophoresis, into six main components, which include lysozyme (Barton \& Wiesner, 1945; Pommerenke, 1946; Moghissi \& Neuhaus, 1962; Schumacher, Strauss \& Wied, 1965). Rozansky, Persky \& Bercovici (1962) suggested that the antimicrobial activity could be associated with lysozyme-like activity and Schumacher (1968), using a semiquantitative micro method, showed that the concentration of lysozyme varied between 0.5 and $100 \mathrm{mg} / 100 \mathrm{ml}$ cervical mucus.

The antimicrobial activity of bovine cervical mucus has received relatively little attention. Gibbons (1959) reported the presence of lysozyme activity on Micrococcus lysodeikticus in the native mucin of bovine cervical mucus, but he made no mention of any antimicrobial properties.

The presence of lysozyme in cattle has been disputed. Its complete absence has been reported in bovine leucocytes, tears, nasal exudates and saliva (Padgett \& Hirsch, 1967), though Chandan, Parry \& Shahani (1968) detected very low levels in milk.

Pierce (1959), in a review of the specific antibodies found on mucus surfaces, suggested that they can provide a defence system in the bovine genital tract against the non-invasive, mucus-bound, infectious agents such as Trichomonas 
foetus. On the other hand, he considered that there may also be a non-specific local resistance. The results reported in this paper are an investigation into this non-specific property of bovine cervical mucus with special reference to lysozyme.

\section{MATERIALS AND METHODS}

Clear mucus was collected from the external os of the cervix of cows during oestrus, using a sterile speculum. The amount of mucus obtained from each cow varied between 5 and $200 \mathrm{ml}$, depending on the cow and the stage of oestrus. On occasions, it was necessary to collect from several cows in order to obtain 200-ml batches. Immediately after collection, the individual samples were pooled and stored at $-20^{\circ} \mathrm{C}$.

\section{The isolation of anionic and cationic proteins from cervical mucus}

Approximately $200 \mathrm{ml}$ cervical mucus thawed at room temperature were diluted with an equal volume of $0.5 \mathrm{M}-\mathrm{NaCl}$ and shaken on a mechanical shaker for $90 \mathrm{~min}$ to give a complete dispersion. The mixture was centrifuged at $30,000 \mathrm{~g}$ for $90 \mathrm{~min}$ and the supernatant was removed; the gel deposit was again suspended in $0.5 \mathrm{M}-\mathrm{NaCl}(200 \mathrm{ml})$, allowed to stand overnight at $4^{\circ} \mathrm{C}$ and recentrifuged at $30,000 \mathrm{~g}$ for $90 \mathrm{~min}$. The supernatants from the two centrifugations were pooled and checked for bacterial contamination by plating out $0.2 \mathrm{ml}$ on blood agar plates. If bacterial contamination was severe, the whole sample was discarded but, if slight, then the supernatant was filtered through a millipore filter (mean pore size-0.22 $\mu \mathrm{m}$ ). Sterile supernatants were dialysed against five changes of 5 litres double glass-distilled water to remove the $\mathrm{NaCl}$ and any small molecular weight components. Any euglobulin precipitate formed during the dialysis was removed by centrifugation and the supernatant was further dialysed against three changes of 5 litres $0 \cdot 1$ M-acetate buffer of $\mathrm{pH} 4.2$ at $4^{\circ} \mathrm{C}$.

This dialysed solution was chromatographed on a CM-cellulose (Whatman C.M.70) column which had been washed previously with $0.5 \mathrm{M}-\mathrm{HCl}$ before equilibrating with an $0.1 \mathrm{M}$-acetate buffer, $\mathrm{pH} 4.2$. The unbound anionic protein fraction, which washed through the column with the acetate buffer, was monitored for protein content at $280 \mathrm{~nm}$ by an L.K.B. 8300 Uvicord II. When extensive washing of the column with the buffer showed no further evidence of protein, the cationic proteins were eluted as a single protein peak with $0.2 \mathrm{~m}-\mathrm{HCl}$ (Text-fig. 1), dialysed against double glass-distilled water and freezedried.

\section{Production of specific antisera to cervical mucus cationic protein extract}

Of the cationic protein fraction, $2 \mathrm{mg}$ were made soluble in $2 \mathrm{ml}$ phosphate buffer and emulsified with $2 \mathrm{ml} 4.0 \%$ (w/v) sodium alginate adjuvant (Medical Alginates Ltd, Middx, England). The emulsion ( $2 \mathrm{ml}$ ) was injected intramuscularly into a New Zealand White rabbit and a similar injection was given 2 weeks later. After a further 3 weeks, a course of six intravenous injections $(0.5 \mathrm{mg}$ protein $/ 0.2 \mathrm{ml}$ phosphate buffer) was given at weekly intervals and a blood sample was collected 4 days after the last injection. 
Antimicrobial assays

Staphylococcal assay. Approximately $1.0 \mathrm{mg}$ freeze-dried protein was gently shaken with $2.0 \mathrm{ml} \mathrm{0.1} \mathrm{M}$-phosphate buffer $\left(\mathrm{NaH}_{2} \mathrm{PO}_{4}, \mathrm{Na}_{2} \mathrm{HPO}_{4}\right), \mathrm{pH} 7 \cdot 0$, for several minutes. The undissolved protein was removed by centrifugation at $2000 \mathrm{~g}$ for $10 \mathrm{~min}$ and the protein content of the supernatant was estimated (Lowry, Rosebrough, Farr \& Randall, 1951).

A 6-hr culture of Staphylococcus aureus, S305, was prepared from an overnight culture grown in a medium for assaying riboflavin (Difco Laboratories, Detroit, Michigan, U.S.A.) to which ribollavin was added $(25 \mu \mathrm{g} / 100 \mathrm{ml})$. The organisms in their log phase of growth were diluted in a citric acid buffer at $\mathrm{pH} 7 \cdot 0$

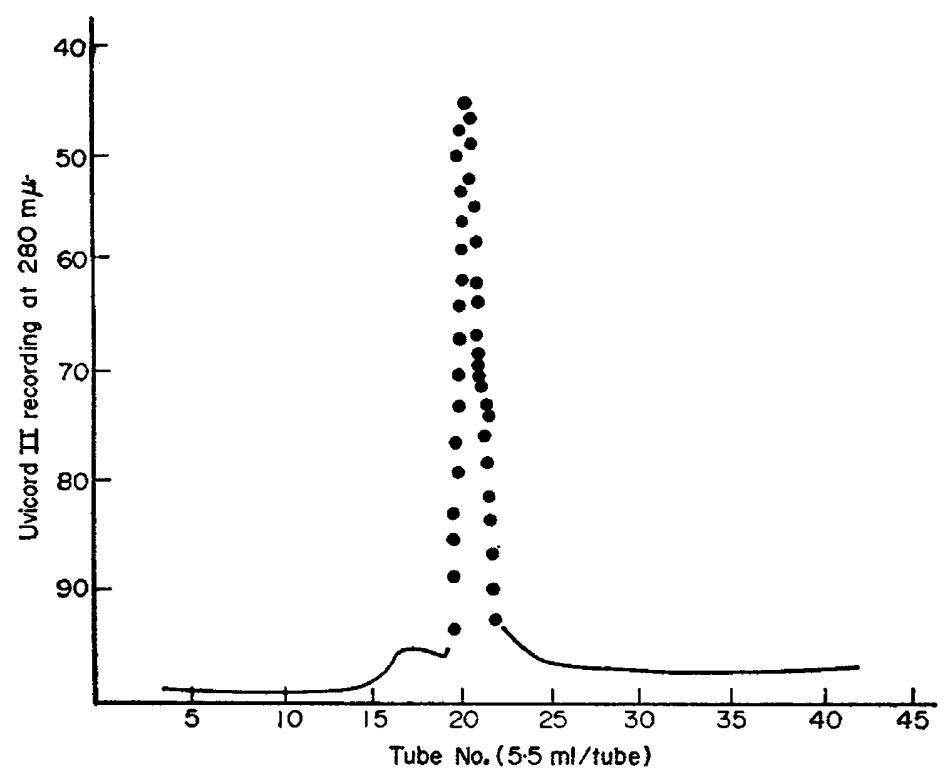

TEXT-FIg. 1. Cervical mucus cationic protein peak eluted from CM-cellulose with $0 \cdot 2$ $\mathrm{M}-\mathrm{HCl}$.

$\left(0.01 \mathrm{M}\right.$-citric acid, $\left.0.01 \mathrm{M}-\mathrm{Na}_{2} \mathrm{HPO}_{4}\right)$ to give a final concentration of 1 to $1.5 \times 10^{3}$ colony-forming units $/ \mathrm{ml}$. The antimicrobial activity of the protein fractions against the staphylococci was estimated by the method of Hirsch (1958) as modified by Hibbitt, Cole \& Reiter (1969). The following proteins were assayed: egg white lysozyme, bovine $\gamma$-globulin Cohn Fraction II (Sigma Chemical Laboratories), the anionic and cationic proteins isolated from cervical mucus and the synthetic polypeptide poly-1-lysine (M.W. 50,000, Koch-Light, Bucks., England). The latter compound was used as a standard in all the assays to detect any changes in the assay system and in the susceptibility of the assay organism.

Brucella assay. A 48-hr growth of an aerobic Brucella abortus S19 organism (obtained from Compton stock) on an albimi agar slope was suspended in $1.0 \mathrm{ml} \mathrm{0} \cdot 1 \mathrm{~m}$-phosphate buffer $\left(\mathrm{Na}_{2} \mathrm{HPO}_{4}, \mathrm{NaH}_{2} \mathrm{PO}_{4}\right)$ at $\mathrm{pH} 7 \cdot 0$. The sus- 
pension was then used to inoculate an albimi agar plate containing 4-mm diameter wells. The wells were filled with dilutions of the protein solutions already described for the staphylococcal assay (see above) and the plates were incubated at $37^{\circ} \mathrm{C}$ for $24 \mathrm{hr}$. Clear zones around the wells were taken to indicate an inhibition of the growth of Brucella abortus S19.

Lysozyme assay. Lysozyme was estimated by the Parry, Chandan \& Shahani (1965) modification of the procedure described by Shugar (1952). A semiquantitative method was also used in which inhibition zones were measured around wells cut in poured plates containing a suspension of Micrococcus lysodeikticus in buffered noble agar (Schumacher \& Wied, 1966).

\section{Electrophoresis of cervical mucus proteins}

Disc electrophoresis. The heterogeneity of the isolated proteins was resolved by disc electrophoresis on polyacrylamide gels (Davis, 1964) made up in a $0 \cdot 2$ $\mathrm{M}-\mathrm{Na}_{2} \mathrm{HPO}_{4}$-citric acid buffer at $\mathrm{pH} 3 \cdot 0$. A current of $2 \mathrm{~mA} /$ tube $(0.5 \mathrm{~cm}$ in diameter) was applied for $10 \mathrm{~min}$ to allow for spacing followed by $4 \mathrm{~mA} /$ tube for $80 \mathrm{~min}$. The gels were removed from the glass holding tubes, fixed and stained simultaneously in $1 \%$ Amido black (George T. Gurr Ltd, London) in $7 \%$ acetic acid for $30 \mathrm{~min}$. They were decolourized by immersion in several changes of $7 \%$ acetic acid.

Immunoelectrophoresis. A modification of the micro method of Scheidegger (1955) was used, in which a $1 \%$ agarose gel made up in a $0.1 \mathrm{~m}$-barbitone acetate buffer $\mathrm{pH} 8.6$ (Oxoid Ltd) was poured on to glass slides measuring $4.5 \times 6.0 \mathrm{~cm}$. Electrophoresis was carried out at a potential of approximately $16.5 \mathrm{~V} / \mathrm{cm}$ for $45 \mathrm{~min}$.

Following electrophoresis, the presence of serum proteins in cervical mucus was determined by testing for the development of a precipitin pattern against a commercial preparation of rabbit anti-cow serum (Wellcome Reagents Ltd).

To find the position of lysozyme, purified egg white lysozyme (Worthington Biochemical Corporation, Freehold, N.J., U.S.A.), as well as the cervical mucus fractions, was run as outlined above, but the step with the antiserum was omitted. The slide was stained with $1 \%$ Amido black in $7 \%$ acetic acid.

Isoelectric focusing. Polyacrylamide gel isoelectric focusing was carried out in a disc electrophoresis apparatus as described by Wrigley (1968). In these experiments, the $\mathrm{pH} 7$ to 10 carrier ampholytes (L.K.B. Instruments Ltd) were used and were incorporated $(2 \%)$ into the polyacrylamide gel which contained riboflavine to assist polymerization in u.v. light. A $5 \% \mathrm{NNN}^{\prime} \mathrm{N}^{\prime}$ tetramethylethylene-diamine solution was placed in the cathode chamber and a $5 \%$ orthophosphoric acid solution in the anode chamber. A potential of $100 \mathrm{~V}$ was applied to eight gels $(7.5 \times 0.5 \mathrm{~cm})$ for $6 \mathrm{hr}$ at room temperature. The gels were stained in $0.2 \%$ brom-phenol blue stain which selectively stained the protein in the presence of carrier ampholytes (Awdeh, 1969). Diagrammatic records were made since the faintly staining bands soon became decolourized.

The $\mathrm{pH}$ gradient in the gels was measured after electrophoresis and before staining. A representative gel in the electrophoresis experiment was cut into a series of $0.5-\mathrm{cm}$ lengths, each section was broken up in $1 \mathrm{ml}$ double glassdistilled water with a glass rod and allowed to stand for $1 \mathrm{hr}$ at $4^{\circ} \mathrm{C}$. The $\mathrm{pH}$ of 
the suspension was then observed, using a $\mathrm{pH}$ meter with minimum scale divisions of 0.02 (Pye Model 291, Pye Unicam Ltd, Cambridge, England).

\section{RESULTS}

The total soluble protein content of four bulk samples of native cervical mucus obtained from cows during oestrus varied between 0.8 and $1.2 \mathrm{mg} / \mathrm{ml}$. The purification of these proteins on CM-cellulose columns resulted in the classi-

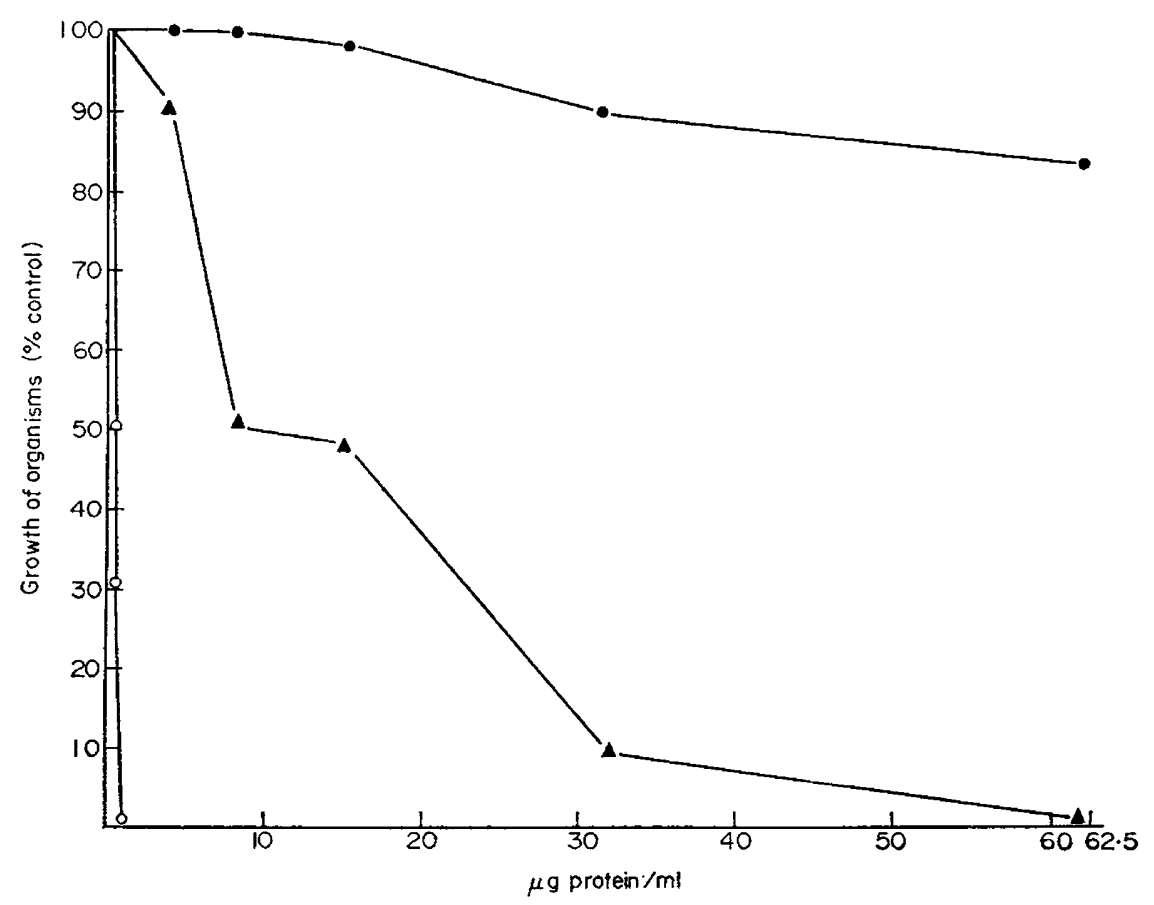

TEXT-FIG. 2. The inhibitory effect of proteins isolated from bovine cervical mucus on the growth of Staphylococcus aureus S305. $\bullet$, Anionic cervical mucus fraction; $\Delta$, cationic cervical mucus fraction; 0 , poly-1-lysine.

fication of $48 \%$ (bound fractions) as cationic and $52 \%$ (unbound fractions) as anionic.

Antimicrobial activity of extracted proteins

Staphylococcal assay. The cationic proteins isolated from the cervical mucus had an inhibitory effect on the growth of staphylococci with protein concentrations as low as 10 to $15 \mu \mathrm{g} / \mathrm{ml}$, producing a $50 \%$ inhibition of growth. The anionic proteins had no effect at concentrations as high as $250 \mu \mathrm{g} / \mathrm{ml}$. Both groups of proteins were assayed in triplicate together with the synthetic polypeptide poly-1-lysine; a typical result of these assays presented as mean values is shown in Text-fig. 2. It may be seen from this figure that the polyl-lysine was very inhibitory with concentrations of less than $1.0 \mu \mathrm{g} / \mathrm{ml}$ producing a $50 \%$ inhibition of growth. In another series of assays under exactly 
the same conditions, the antimicrobial activities of bovine serum $\gamma$-globulin and egg white lysozyme showed no antimicrobial activity, even at concentrations as high as $250 \mu \mathrm{g} / \mathrm{ml}$.

Brucella assay. The concentration of the protein in this assay was $50 \mu \mathrm{g} / \mathrm{ml}$ and $100 \mu \mathrm{l}$ of the solution were used to fill the wells. There was an early detectable zone of inhibition around the well containing the cationic proteins after a 24-hr incubation at $37^{\circ} \mathrm{C}$, but no inhibition around wells containing the anionic proteins, egg white lysozyme or bovine serum $\gamma$-globulin. Plate 1 shows the two wells that contained anionic and cationic protein fractions after a 24-hr incubation.

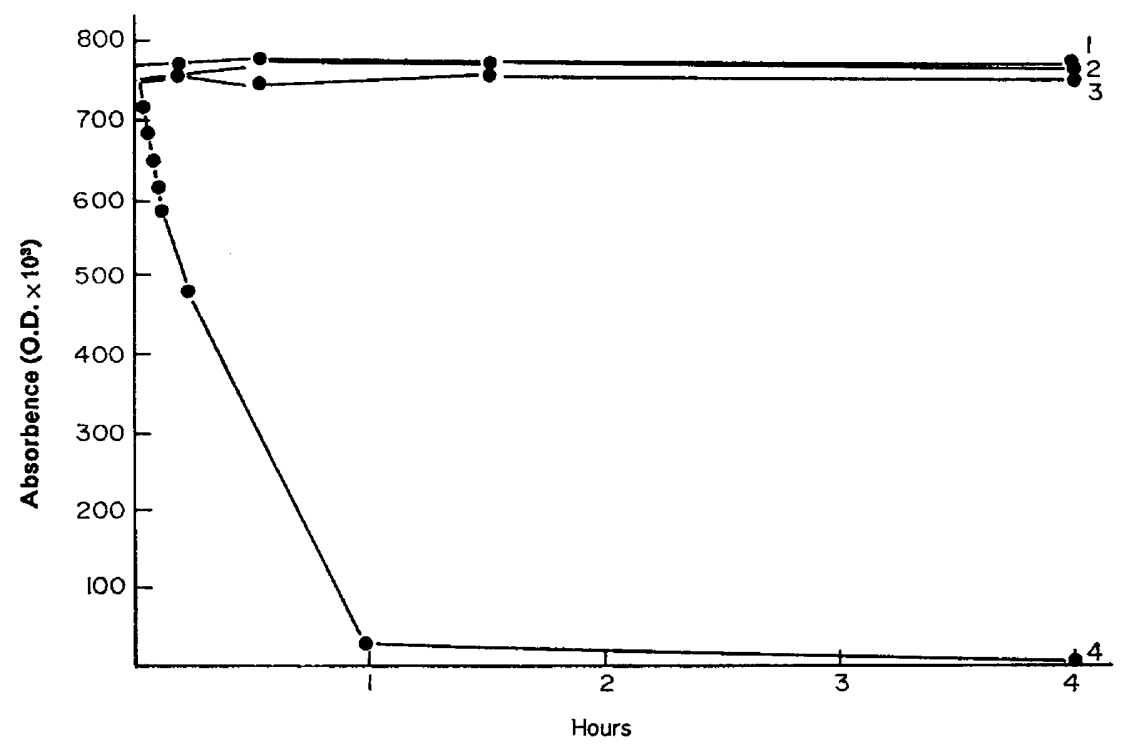

TExT-FIG. 3. Lysozyme assay on proteins isolated from bovine cervical mucus. 1, Blank; 2 , anionic cervical mucus fraction $4 \mathrm{mg} / \mathrm{ml} ; 3$, cationic cervical mucus fraction $4 \mathrm{mg} / \mathrm{ml}$; 4 , egg white lysozyme standard $0.05 \mathrm{mg} / \mathrm{ml}$.

Lysozyme assay. No absorbency decrease was observed when a suspension of Micrococcus lysodeikticus was incubated for periods of up to $4 \mathrm{hr}$ with either of the fractions of the cervical mucus. Nevertheless, under similar experimental conditions, a standard solution of egg white lysozyme produced a predictable initial rate of absorbency decrease (Text-fig. 3). The apparent absence of lysozyme in the cervical mucus-soluble proteins, indicated by this technique, was confirmed in the procedure described by Schumacher (1968) when no zones of bacteriolysis developed around the wells containing the cervical mucus protein. Different samples of the original native cervical mucus were also placed in the wells but there was no evidence of bacteriolysis.

\section{Electrophoresis of cervical mucus proteins}

Polyacrylamide gel disc electrophoresis studies indicated that the cervical mucus cationic protein fraction was heterogeneous. Text-figure 4 shows that at 


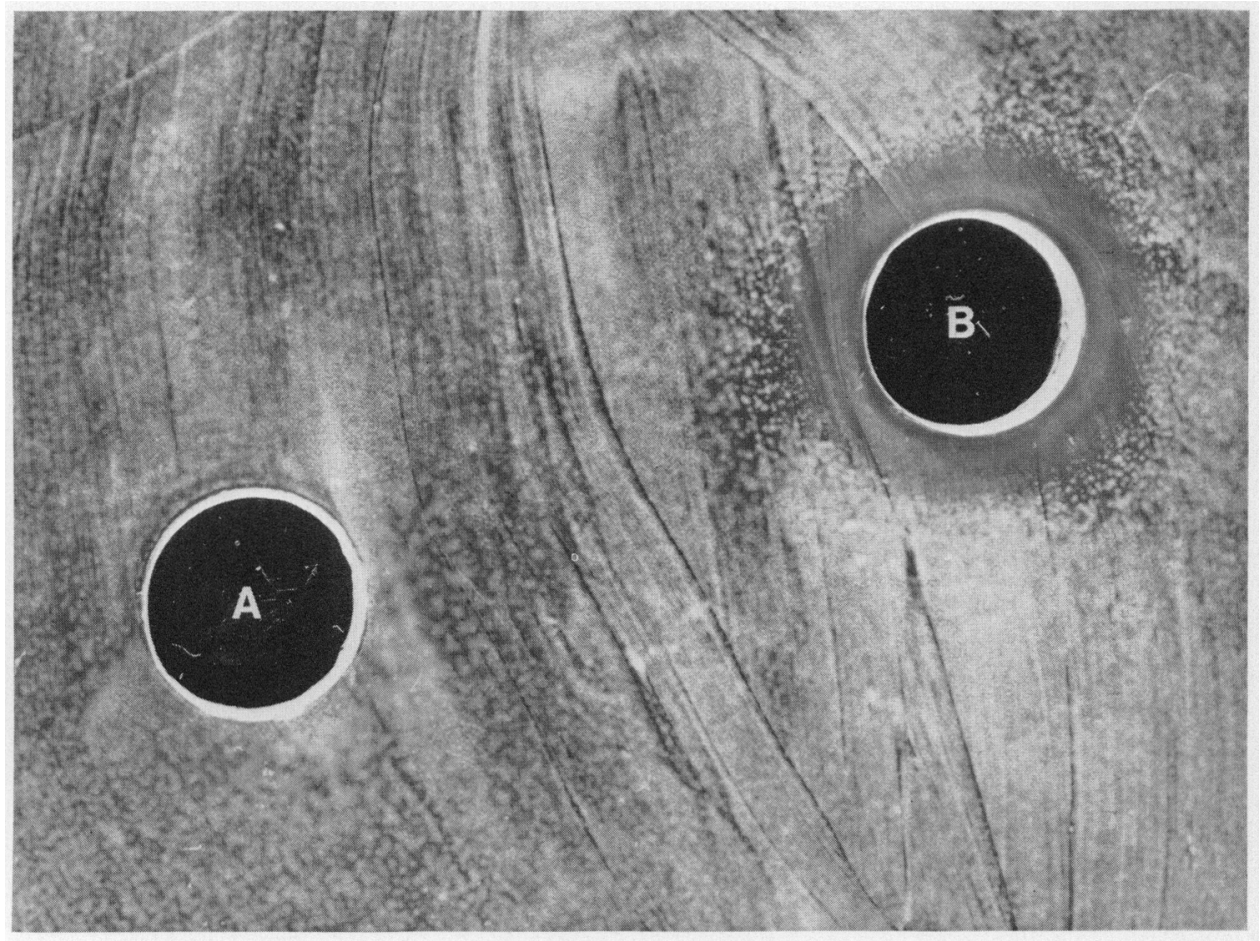

Albimi agar plate sceded with Brucella abortus showing the effect of cervical mucus protein fractions. (A), Anionic proteins from corvical mucus: B. cationic proteins from cervical mucus. 
$\mathrm{pH} \mathrm{3.0} \mathrm{the} \mathrm{proteins} \mathrm{can} \mathrm{be} \mathrm{separated} \mathrm{into} \mathrm{four} \mathrm{separate} \mathrm{fractions,} \mathrm{all} \mathrm{of} \mathrm{which}$ move towards the cathode. However, electrophoresis at $\mathrm{pH} 8.6$ on agarose (Text-fig. 5c) revealed only one distinct fraction migrating towards the cathode with the rest of the protein remaining poorly resolved near the point of application. The strongly basic fraction clearly separated but could not be identified with lysozyme which, under the same conditions, moved more rapidly towards the cathode (Text-fig. 5d). Electrophoresis of the anionic protein fraction on

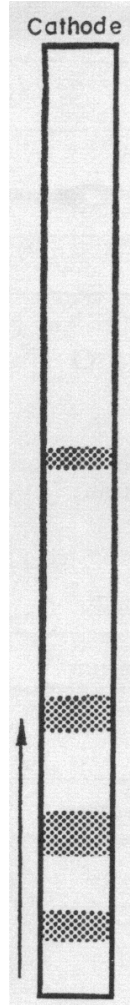

Text-rig. 4. Polyacrylamide disc electrophoresis of the cationic fraction from bovine cervical mucus.

agarose at pH 8.6 separated only one protein completely (Text-fig. 5a) which moved towards the anode. Comparing it with the electrophoresis pattern for whole bovine serum (Text-fig. 5b), this coincided with the position of albumin.

Immunoelectrophoresis. The presence of serum proteins in cervical mucus was investigated further by immunoelectrophoresis studies using rabbit anti-cow serum. Text-figure $6(\mathrm{~b})$ shows that the anionic fraction produced precipitin lines against the antiserum in a position coinciding with that of albumin. Furthermore, other serum components appeared to be present since two clear precipitin lines associated with the cationic fraction (Text-fig. 6c) were in approximately the same position as the $\beta$ - and $\gamma$-globulins.

With rabbit anti-cow cervical mucus cationic protein serum in the troughs, 
one distinct and one faint precipitin line developed which had no corresponding identity with serum precipitin lines (Text-fig. 7).

Isoelectric focusing. The isoelectric focusing of the cationic fraction of cervical

(a)

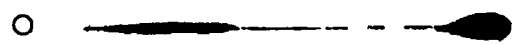

(b)

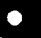

(c)

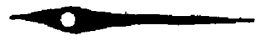

(d)

$(-)$

0

Text-rig. 5. Agarose slide electrophoresis. (a) Anionic cervical mucus fraction; (b) bovine serum; (c) cationic cervical mucus fraction; (d) egg white lysozyme.

(a)

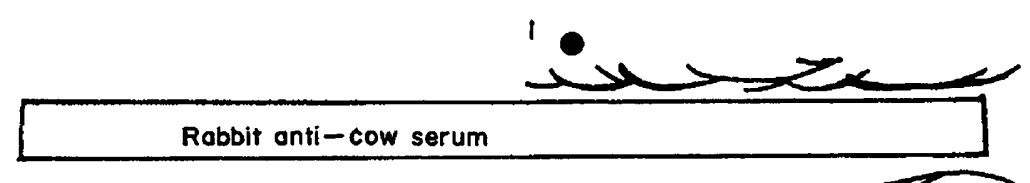

(b)

2

Rabbit anti-cow serum

(c)

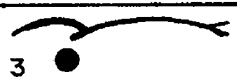

$(-)$

TEXT-FIG. 6. Agarose immunoelectrophoretic analysis of bovine cervical mucus fractions. (a) Bovine serum; (b) anionic cervical mucus fraction; (c) cationic cervical mucus fraction.

(a)

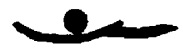

Rabbit antl-cow cationic cervical mucus froction

(b)

$(+)$

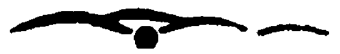

(一)

TEXT-Fig. 7. Agarose immunoelectrophoresis analyses of the bovine cervical mucus cationic fraction. (a) Bovine serum. (b) cationic cervical mucus fraction.

mucus proteins on polyacrylamide gels containing an ampholine $\mathrm{pH}$ range from 7.0 to 10.0 is shown in Text-fig. 8. Most of the proteins separated had isoelectric points between $\mathrm{pH} 7 \cdot 0$ and $8 \cdot 6$. It is noteworthy that one fraction 
focused at $\mathrm{pH} 9.2$ which was possibly the very basic fraction observed in the agarose electrophoresis studies described above (Text-fig. 5c).

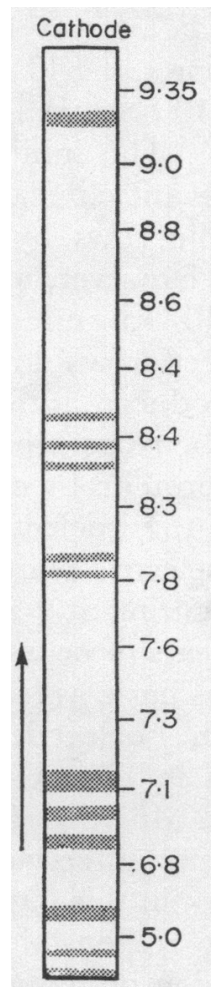

TexT-Fig. 8. Polyacrylamide disc isoelectric focusing of the cationic fraction from bovine cervical mucus.

\section{DISGUSSION}

The presence of non-specific antimicrobial factors in cervical mucus is relevant to a fuller understanding of the causes of infertility. In human cervical mucus, lysozyme has been shown to be present and is responsible for anti-staphylococcal activity (Barton \& Weisner, 1945) and anti-streptococcal activity (Pommerenke, 1946). Rozansky et al. (1962) reinvestigated this property and found the presence of no antimicrobial substance other than lysozyme. In bovine cervical mucus, however, this does not appear to be the case. Lysozyme was not detected by the assays used in this work and, if present, must be in concentrations too low to have any significant antimicrobial activity. The absence of lysozyme has already been reported for bovine tears, saliva, nasal exudates and peritoneal leucocytes (Padgett \& Hirsch, 1967) and bovine milk cells (Hibbitt, Brownlie \& Cole, 1971). The levels of lysozyme reported to be present in bovine cervical mucus by Gibbons (1959) have not been confirmed in this study.

The assay of the isolated fractions from the cervical mucus showed that only the cationic proteins had any marked antimicrobial activity against Staphylococ- 
cus $\mathrm{S} 305$; and as little as 10 to $15 \mu \mathrm{g}$ protein were necessary to produce a $50 \%$ inhibition of growth.

With the brucella assay, the Brucella abortus S19 was the most convenient strain of organism to use in our laboratory because of its modified virulence. There are, however, several reports of S19 causing abortion in adult cattle, following vaccination with the S19 organism (Haring, 1938; Birch, Gilman \& Stone, 1943; McDiarmid, 1951). The inhibition of Brucella abortus S19, reported in this work, may be relevant clinically since the spread of brucellosis from infected bulls to susceptible cows by natural infection has not been demonstrated (Thomsen, 1943). However, artificial intrauterine insemination with brucella-infected semen will transmit brucellosis (Manthei, DeTray \& Goode, 1950). The barrier to infection would appear to be the cervix where, in the absence of specific locally-produced antibodies (Kerr, Pearson \& Rankin, 1958), non-specific factors must be responsible.

The resolution of the cationic proteins by electrophoresis showed that several basic proteins were present and the isoelectric focusing of these proteins demonstrated that most of their isoelectric points were between 7.0 and 8.6 , with the exception of a single band focusing at 9.2. This component developed as a faint band (Text-fig. 7) and appears to be a cervical mucus component rather than a serum one, but it is not as basic as lysozyme which Alderton, Ward \& Fevold (1945) indicated has an isoelectric point between 10.5 and 11.0. The presence of serum proteins in the soluble protein fractions of cervical mucus was not surprising since Moghissi \& Neuhaus (1962), in their immunoelectrophoretic studies on human cervical mucus, also detected albumin and $\beta$ - and $\gamma$-globulins. The work in this paper suggests that non-serum antimicrobial basic proteins may be responsible for providing an initial line of defence for the uterus from invasion by pathogenic micro-organisms.

\section{ACKNOWLEDGMENTS}

We wish to thank Dr A. McDiarmid for supplying the Brucella abortus culture and for his advice on its cultivation. We also wish to thank Dr J. C. Boursnell and Dr U. Lavon for their discussion and help with the isoelectric focusing technique.

\section{REFERENCES}

Alderton, G., Ward, W. H. \& Fevold, H. L. (1945) Isolation of 'lysozymes' from egg-white. $\mathcal{F}$. biol. Chem. 157, 43.

AwDEH, Z. L. (1969) Staining method for proteins after isoelectric focusing in polyacrylamide gel. Sci. Tools, 16, 42.

Barton, M. \& Wiesner, B. P. (1945) Studies on the biology of the cervix. Ir. F. med. Sci. 6, 567.

BiRch, R. R., Griman, H. L. \& Stone, W. S. (1943) The pathogenicity of Brucella abortus strain 19 for sexually mature cattle. Cornell Vet. 33, 198.

Ghandan, R. G., Parry, R. M., Jr \& Shahani, K. M. (1968) Lysozyme, lipase and ribonuclease in various species. 7. Dairy Sci. 51, 606.

DAvis, B. J. (1964) Disc electrophoresis. II. Method and application to human serum proteins. Ann. N.Y. Acad. Sci. 121, 404.

Grbbons, R. A. (1959) Chemical properties of two mucoids from bovine cervical mucus. Biochem. 7 . 73, 209. 
HARING, C. M. (1938) Vaccination against Bang's Disease in an infected dairy herd with U.S.B.A.1. Brucella abortus strain 19. 7. Am. vet. med. Ass. 92, 52.

HibbitT, K. G., Brownlre, J. \& Cole, G. B. (1971) The antimicrobial activity of cationic proteins isolated from cells in bulk milk samples. F. Hyg., Camb. 69, 61 .

Hibbitt, K. G., Cole, C. B. \& Rerter, B. (1969) Antimicrobial proteins isolated from the teat canal of the cow. F. gen. Microbiol. 56, 365.

Hrrsch, J. G. (1958) Bactericidal action of histone. F. exp. Med. 108, 925.

Kerr, W. R., Pearson, J. K. L. \& Rankin, J. E. F. (1958) Brucellosis survey in dairy herds with particular reference to diagnostic methods including the vaginal mucus test. Vet. Rec. 70, 503.

Lowry, O. H., Rosebrough, N. J., Farr, A. L. \& Randall, J. R. (1951) Protein measurements with the folin-phenol reagent. $\mathcal{F}$. biol. Chem. 193, 265.

McDiaRmid, A. (1951) The vaccination of pregnant cattle with strain $19 \mathrm{Br}$. abortus vaccine during an outbreak of brucellosis in a dairy herd. Vet. Rec. 63, 265.

Manthei, G. A., DeTray, D. E. \& Goode, E. R. (1950) Brucella infection in bulls and the spread of brucellosis in cattle by artificial insemination. Proc. Am. vet. med. Ass., 87th Ann. Meet. p. 177.

Mognissi, K. S. \& Nevhaus, O. W. (1962) Composition and properties of human cervical mucus. Immunoelectrophoretic studies of the proteins. Am. J. Obstet. Gynec. 81, 149.

Padgetr, G. A. \& Hirsch, J. G. (1967) Lysozyme, its absence in tears and leucocytes of cattle. Aust. $\mathcal{F}$. exp. Biol. med. Sci. 45, 569.

Parry, R. M., Chandan, R. C. \& Shahani, K. M. (1965) A rapid and sensitive assay of muramidase. Proc. Soc. exp. Biol. Med. 119, 384.

PIerce, A. E. (1959) Specific antibodies at mucous surfaces. Vet. Revs Annot. 5, 17.

Pommerenke, W. T. (1946) Cyclic changes in the physical and chemical properties of cervical mucus. Am. F. Obstet. Gynec. 52, 1023.

Rozansky, R. A., Persky, S. \& Bercoviar, B. (1962) Antibacterial action of human cervical mucus. Proc. Soc. exp. Biol. Med. 110, 876.

SchemegGer, J. J. (1955) Une microméthode de l'immunoélectrophorèse. Int. Archs Allergy appl. Immun. $7,103$.

Schumacher, G. F. B. (1968) Protein analysis of secretions of the female genital tract. F. Reprod. Fert. $1,61$.

Schumacher, G. F. B., Strauss, E. K. \& Wied, G. L. (1965) Serum proteins in cervical mucus. Am. F. Obstet. Gynec. 91, 1035.

Schumacher, G. F. B. \& Wied, G. L. (1966) Semiquantitative microanalysis of proteins in cervical mucus. Proc. Vth Wld Congr. Fert. Steril., Stockholm. Eds. A. I. Sundberg and B. Westin. Excerpta med. Fdn, Amsterdam.

ShugaR, D. (1952) The measurement of lysozyme activity and the ultraviolet inactivation of lysozyme. Biochim. biophys. Acta, 8, 302.

Thomsen, A. (1943) Does the bull spread infectious abortion in cattle? Experimental studies from 1936 to 1942. J. comp. Path. Ther. 53, 199.

WRIGLEY, G. W. (1968) Analytical fractionation of plant and animal proteins by gel electro focusing. 7. Chromat. 36, 362. 